\title{
Europe and psychiatric ethics
}

\author{
Jim van Os and Jan Neeleman
}

\begin{abstract}
European integration confronts both Individual poychictitits and poychiatile senvice plenners with ethicel aliemmes thet should beet bo dectt with procetivety by modical and poychiatile organiseations. selected excmples are presented of ethical laswes outsing out of difierences in peychiotitic proctice across Europe. Some of the ethicel implications moy seem relatively minor, but still require a major adjustiment effort on the pait of poychictitits who are exposed to trensecuthural proctice in the Europecen Union. Other oxamples hove been selected, not becouse thoy are common, but becouses of their moselve ethice remilications.
\end{abstract}

Where there are gaps in psychiatric knowledge, individual beliefs will inevitably come to fll them. These beliefs may to a large extent be determined by sociocultural and historical factors. Given the increasingly international arena of psychiatric practice within the European Union, perceptions of right and wrong associated with local convictions are coming more to the fore. Contrasting approaches to psychiatric care may lead to ethical dilemmas, not only in theory, but also in reality now that doctors in the European Union can practise in any country.

Thirty-six European nations in the WHO European Region have recently signed the 'Declaration on The Promotion of Patients' Rights in Europe' and this document, although not passed through the European machinery yet, will regulate cruclal aspects of the doctor/patient relationship such as consent, right to treatment, right to a second opinion, right to a written diagnosis on discharge and also the right to refuse treatment. Some issues of relevance to these regulations are discussed below.

\section{Patients' rights and the Mental Eealth Act}

The Councll of Europe has announced the forthcoming publication of a European Convention of Blo-ethics. Of relevance to psychiatry is, for example, recommendation
$R(83) 2$ on the protection of persons suffering from mental disorders, placed as involuntary patients. Who should be empowered to detain individuals in a psychiatric hospital and/or treat them against their will? A visiting German psychiatrist practising in several Länder (federal states in Germany), commented to the authors on the unease he was sure some of his British colleagues must feel while arranging for their patients to be compulsorlly admitted under the Mental Health Act. From the patient's point of view, he argued, a procedure involving a (often psychiatric) social worker and two medical practitioners, one of them involved in his treatment, cannot be experienced as impartial and independent. He was happier with a system where the psychiatrist merely functioned as applicant, and where the final decision to detain and/or treat was made by the judge or his representative. It is arguable that such a visible separation of clinical and legal responsibilities would contribute to a healthier working relationship with his client, would be less burdensome for the psychiatrist in terms of liability, and would therefore be less likely to lead to 'overkill' in detaining patients.

There is evidently a distinction between countries where detention in hospital is a largely clinical decision (e.g. France and England) v. those where the judge or other representative from the legal profession is ultimately responsible (e.g. Austria, The Netherlands, most of Germany). A recent audit in a large centre in the Netherlands revealed that almost $60 \%$ of involuntary admissions requested by the clinician had been quashed by the judge within on average five days of detention (Nijman et al, 1993). In the same country, before the recent Introduction of the new Mental Health Act, it was not rare to find patients detained in hospital, yet without being required to accept any form of treatment.

The European Court of Human Rights (part of the Council of Europe) has had noticeable effects on mental health practice in a number of European countries. In the United Kingdom, 
the 1993 Mental Health Act was drafted partly in response to European Court judgments condemning the absence of judicial rights of appeal for detained patients. Similarly, in France, the Mental Health Law of 27 June 1990 has been drafted to meet the requirements of recommendation $R(83) 2$ by the Councll of Europe.

\section{Treatment issues}

Psychiatrists cannot prescribe freely the same treatments in the countries of the European Union, as there are widely differing perceptions regarding the acceptability and efficacy of certain therapies. In Germany and the Netherlands, for example, electroconvulstve therapy (ECT) has fallen into disgrace and is, compared to the UK and France only sporadically applied. However, full psychoanalysis is avallable in the Netherlands on insurance (private contribution approximately $\& 1$ per session) while in Britain those who want such treatment typically have to pay upwards of $£ 30$ per session. In practice, there is virtually no psychoanalysis avallable on the NHS, and insurance companies in the UK will not pay for psychodynamic psychotherapy. This is partly the result of the state health system. and partly the result of UK psychiatrists' views. On the other hand, patients with anxdety disorders in, for example, theNetherlands may experience difficulties finding a cognittvebehavioural psychotherapist, espectally among psychiatrists, some self-help organisations hiring their own behavioural therapists to fill the gap (Brusse, 1993). In some other countries, longer-term treatment with benzodiazepines for such disorders is common, and considered a relattvely safe and efficacious remedy (Van Os \& Neeleman, 1994a).

Thus, a psychiatrist trained in one country may find that his treatments are considered unethical in the other, or that he is considered negligent because he falls to prescribe the right therapy. For example, withholding ant1hypotensive medication to some patients on antipsychotics would be considered bad practice by many in France, but not referring an actively psychotic patient for psychodynamic psychotherapy. Even the application of apparently similar treatments may violate local moral precepts; a continental Lacaniantrained psychoanalyst may be well respected in his own country, but frowned upon by his Kleinian counterpart in the UK.
Patients and relattves may oblige the therapist to revise his concepts on what constitutes the 'right' treatment. A Northern European family therapist, for example, may have to readjust his views on expressed emotion in the family as a risk factor of early relapse in schizophrenia, while working in southern Europe. Equally, the cognittve therapist, confident of the effectiveness of his therapy (established in mostly Anglo-Saxon trials) may find that he cannot easily convince clients from a different cultural background of his treatment rationale.

Private psychiatric practice is more prominent in countries with insurance-based health care systems, which may affect the quality of care recetved by psychotic compared to neurotic patients (Van Os \& Neeleman, 1994b). Conversely, people with psychotic disorders are generally given a higher priority than those with neuroses in the NHS.

Oplate addicts in Amsterdam or Barcelona are likely to be left alone by both police and psychiatrists, unless they commit an offence other than mere possession, or if they request help. Medical care, including low threshold methadone maintenance, is widely available to those who wish It. In the UK, the same group is at substantially increased risk of being penalised, as mere possession of a controlled drug is - and not only in theory - an imprisonable offence. On the other hand, the leading role taken by British psychiatrists in the addictions field contrasts with the low levels of involvement of psychiatrists in this area in some other European countries. The avallability of low threshold methadone maintenance also differs substantially across member states (Van Os \& Neeleman, 1994a). France is the only country in the European Union where the law provides for the psychiatric detention of "alcoholics presumed dangerous" ("La Lol du 15 Avril 1954"). Given the fact that the addictions field has become a focal issue in the Maastricht Treaty, the ethics of such widely divergent approaches requires further consideration.

\section{Poychiatrists and euthanasia}

According to studies in England and the Netherlands, respectively $32 \%$ and $41 \%$ of doctors who had faced a request for active euthanasia reported that they had taken active steps to hasten death (active euthanasia). There is no doubt that psychiatrists are also 
faced with requests for active euthanasia or assisted suicide. Given the fact that such procedures are subject to criminal law throughout Europe, accounts of actual cases and empirical data are not available, with the exception of the Netherlands, where about half of the doctors involved in active euthanasia and assisted suicide report to the judicial authorities, and where since December 1993 the law excludes doctors from the criminal penalties associated with these activities, provided they follow certain guidelines. One case involved a psychilatrist against whom charges were dismissed by both the local and appeal courts, having assisted a physically healthy 50-year-old woman with a mourning process complicated by a depresstve illness, in ending her life. A full discussion of the issues in this case is beyond the scope of this article (reviewed by Van der Lijn et al, 1994), but some are of special interest. The court in such cases needs, among others, to be convinced of the 'untreatability' of the condition. Treatability in a British court would most probably be judged on empirical evidence of failure of an extenstve pharmacological and psychological treatment programme, analogous to current guidelines relating to psychosurgery for intractable depression or obsessivecompulstve disorder. For any depresstve illness, this would include adequate treatment with anti-depressants and ECT if necessary. In the Dutch case, however, the court accepted that the patient was untreatable, even though the psychiatrist's diagnosis included depressive illness and no judgment could be made about response to conventional therapies. The lack of evidence regarding treatment response was, on the one hand, due to the patient's refusal to consider any psychological or biological treatment option, and, on the other hand, to the clinical impression of the psychiatrist that her depresstive lllness was not of the type that would respond to biological interventions (Charbot, 1993). The Solicitor General decided to take the case to the Dutch Supreme Court as a test case. The court ruled, pragmatically, that the psychiatrist was guilty, but would not be punished, and allowed him to continue to practice. The guilty verdict related only to his fallure to have the patient actually examined by a second doctor (although he had discussed her case with six other mental health professionals). The judgment reflected public opinion, which had expressed precious little criticism.
Furthermore, the verdict had special significance as the patient was not terminally ill, thus not legally excluding the possibility of euthanasia or assisted suicide in cases where unbearable suffering is of mental origin, provided the previous guidelines are observed and the patient is examined by other professionals. Subsequently, charges have been dropped in a number of analogous cases which were being considered by the courts. Given these developments, one is led to wonder whether there exists a relative discrepancy between the threshold for effective and reversible treatments such as ECT, and the threshold for assisted suicide in psychiatric practice in the Netherlands.

\section{Comment}

With European integration moving forward, so will the discussion on the rights and wrongs of divergent approaches to psychiatric practice. Given that some of these differences appear to be rooted in different prevalling anthropologles, which are likely to affect both psychiatrists' views and patients' expectations alike, the idea of an imminent general European consensus seems implausible. At this stage, kdndling awareness and promoting further exploration of these issues may facilitate current European initlatives, such as the European Convention of Bio-ethics.

\section{References}

BRUsse, J. (1993) Voor Niets Bang Amsterdam: La Rtvlère \& Voorhoeve.

Charbor, B. E. (1993) Zelf Beschllet Amsterdam: Balans.

NLMAN, H., à CAMPO, J. \& RAVEu, D. (1993) Inbewaringstellingen: kort maar krachtig? Tydschrift voor Psychiatrie, 36, 58-66.

VAN DER LUN, M., NOLEN, W. A. \& SCHUDEL, W. J. (1994) Hulp bj zelfdoding aan psychiatrische patienten. Rechtvaardigingsgronden en zorgvuldigheldscriterla. Tydschrift voor Psychiatrle, s6, 406-417.

VAN OS, J. \& NEELEMAN, J. (1994a) Mental lliness in Europe. Brttish Medical Journal, S09, 1218-1222.

- (1994b) European Union leglslation affecting psychiatric practice. Psychiatric Bulletin, 18, 390-394.

* Jim van Os, Lecturer and MRC Training Fellow, Department of Psychological Medicine, King's College Hospital and Institute of Psychiatry, London SE5 8AF and Jan Neeleman, Senior Registrar, Maudsley and Bethlem Royal Hospital, Denmark Hill, London SE5 8AF

-Correspondence: Institute of Psychiatry, De Crespigny Park, London SE5 8AF 